\title{
The Typology of Imams in the West and Imams in Poland: Past and Present ${ }^{1}$
}

\author{
Agata S. Nalborczyk (iD) https://orcid.org/0000-0002-1280-5338 \\ Zakład Islamu Europejskiego \\ Wydział Orientalistyczny \\ Uniwersytet Warszawski \\ a.nalborczyk@uw.edu.pl
}

\begin{abstract}
Researchers of Islam in the West have noticed that imams working since the 1950s in Western Europe or the United States assume far more responsibilities than their counterparts in traditional Muslim societies. Consequently, further research had to identify and specify the types of imams who perform their service in the West - their most complete typology is the one developed by Niels Valdemar Vinding. However, besides Finland where the Muslim Tatars have lived since the nineteenth century, the classification does not include imams from areas inhabited by the indigenous Muslims.

This study is an attempt to check if the Polish-Lithuanian Tatars living in Poland who have had their imams for centuries would fit into Vinding's typology and if this typology also would work in a diachronic perspective. Literature on the subject was the basis for the research into the situation of imams in the past. Interviews with representatives of particular Muslim organizations served as the basis for the research into the present-day situation.
\end{abstract}

Keywords: Islam, Muslims in Europe, imam, religious leadership, mosque, Poland, PolishLithuanian Tatars

Słowa kluczowe: islam, muzułmanie w Europie, imam, przywództwo religijne, meczet, Polska, Tatarzy polsko-litewscy

\footnotetext{
${ }^{1}$ This text uses simplified English transcription for terms of Arabic origin.
} 


\section{Introduction}

Religious leadership is a constituent of every community's religious life. What is crucial is who assumes the leadership, how it is exercised, what is its educational base, and liturgical role. The Polish-Lithuanian Tatars living in Poland have had their imams for centuries. Still, despite extensive academic literature on the Tatars, their history, and the present day, the research on imams or religious leadership is scarce. ${ }^{2}$ Undeniably, the teachings of imams largely influence the faith, its practice, and the way the believers function in society. Thus, their education and appointment process are essential, and if they come from outside of the local community, they can change the faith of their followers.

In the West, ${ }^{3}$ there have already been significant studies on the Muslim religious leadership, including imams, as they are considered an essential element of, among others, the integration of immigrant communities. Many of the imams have been brought from abroad, which influences their proclaimed approach to religion. Thus, it is vital to investigate the situation of Polish imams in view of the research in the West: whether the Western typologies of imams can be used to describe their Polish counterparts, whether the classifications designed for communities of immigrant origin also work for indigenous Muslims, and whether the continuing presence of Islam (as is the case of Poland) has in any way influenced the way imams have been working. ${ }^{4}$

\section{Who is an imam?}

Before presenting the results of the classification of imams in Western (European or American) Muslim communities, it is crucial to understand who an imam is, his historical and contemporary role among the traditional followers of Islam, and what distinguishes his service.

The word 'imam' is of Arabic origin and appears in the Qur' an, the sacred book of Muslims, 12 times, ${ }^{5}$ mostly as a leader for the people $(2: 124,9: 12,21: 73)$, but also, i.a., a guide $(11: 17 ; 17: 71)$ or a model $(15: 79)$.

2 The following research on the Polish muftiate is a notable exception: A.S. Nalborczyk, Poland, [in:] Islamic Leadership in the European Lands of the Former Ottoman and Russian Empires. Legacy, Challenges and Change, E. Račius, A. Zhelyazkova (eds.), Leiden 2018, pp. 293-313 or eadem, Polish Tatar Women as Official Leaders of Muslim Religious Communities and the Sources of Their Authority, "Comparative Islamic Studies" 2016 (publ. 2019), no. 12 (1-2), pp. 37-54.

${ }^{3}$ In the article, the West signifies Europe and North America, i.e., territories outside of areas inhabited by mostly Muslim traditional societies.

${ }^{4}$ Literature on the subject was the basis for the research into the situation of imams in the past. Interviews with representatives of particular Muslim organizations served as the basis for the research into the present-day situation. Because of its continued presence within the Polish borders, greater emphasis was placed on the situation of imams in the Tatar community.

${ }^{5}$ M. Hashas, J.J. de Ruiter, N.V. Vinding, Kh. Hajji, Imams in Western Europe. Developments, Transformations, and Institutional Challenges, [in:] Imams in Western Europe. Developments, Transformations, and Institutional Challenges, M. Hashas, J.J. de Ruiter, N.V. Vinding (eds.), Amsterdam 2018, p. 20. 
Prophet Muhammad (c. 570-632) was himself a religious leader, namely an imam of the emerging Muslim community, but also a political and military leader. ${ }^{6}$ Consequently, after his death, political leaders, also called imams at that time, conducted prayer (salat), especially the most significant Friday prayer with a sermon (khutba). It changed during the Abbasid rule (750-1258) after the conquest of Persia in the middle of the eighth century when the caliphs and other political leaders discontinued regular conducting of prayers. Since the middle of the ninth century, prayers were led by the chosen from among "those learned in religious matters," while the ruler did it only for special occasions. ${ }^{7}$ When an imam no longer represented political power, he "was in general in charge of the divine service. [...] It was his duty to conduct every salat." $\mathrm{He}$ was assigned to a given mosque (masjid) where he served and maintained order.

Thus, in Sunni Islam the word 'imam' has several meanings, starting from a political leader of a given community, someone who just performs a prayer for a congregation, to someone who is appointed as an imam of a given mosque or, in general, a person learned in religious matters. ${ }^{9}$

Nowadays, however, the term is regularly and almost exclusively used when referring to somebody performing religious service in mosques or prayer rooms (musalla), who has been selected for the position and meets the requirements of Muslim law for this function: it should be a mature and healthy man, without any apparent disability, of an appropriate disposition, and with required religious knowledge. ${ }^{10}$ The election often entailed a given congregation or an appointment from state authorities in the area. Since the beginning of Islam, there was no agreement as to whether such imams should receive remuneration for their service; over time, the practice of paying them from religious endowments (waqfs) developed, while in the Ottoman Empire they received the status of officials and, in addition to prayers, conducted weddings or funerals, and registered newborns. ${ }^{11}$ Frequently, imams were not in charge of managing the funds, the mosque's property or its religious foundation; instead, it was the job of, e.g., local religious judges (qadi) or a group of trusted persons appointed as "the mosque's protectors."

The Western approach to imams tends to regard them as the Christian clergy and treat them as such. As Jane I. Smith notes, "[i]mams are often referred to by nonMuslims as 'clergy,' although such a term is technically incorrect because there is no ordination as such for imams."

${ }^{6}$ For more details see: W. Madelung, Imāma, [in:] The Encyclopaedia of Islam. Second Edition, vol. 3 , B. Lewis, V.L. Ménage, Ch. Pellat, J. Schacht (eds.), Leiden-London 1986, pp. 1163-1169.

7 J. Pedersen, Masdjid, G. The Personnel of the Mosque, [in:] The Encyclopaedia of Islam. Second Edition, vol. 6, C.E. Bosworth, E. van Donzel, W.P. Heinrichs, Ch. Pellat (eds.), Leiden 1991, p. 674.

${ }^{8}$ Ibidem, p. 675.

${ }^{9} \mathrm{C}$. Thiele, Imame in türkisch-sunnitischen Gemeinden in Deutschland. Ihre Rolle und Bedeutung dargestell anhand der Situation in Hamburg, Nordhausen 2010, p. 13. In Shi'a Islam, the word 'imam' not only describes a leader of a community, but also imams who are descendants of the Prophet, chosen and appointed by God to lead the humanity in all aspects of life and to be perfect examples for the believers.

10 A.-S. Fröhlich, Priesterliche Aufgaben im sunnitischen Islam, Hamburg 1997, p. 77.

${ }^{11}$ E. Aslan, E. Erşan Akkılıç, J. Kolb, Imame und Integration, Berlin-New York 2015, p. 39.

12 J.I. Smith, Islamic Leadership in America, [in:] Religious Leadership: A Reference Handbook, Sh.H. Callahan (ed.), Thousand Oaks, CA, 2013, p. 67. Especially state authorities tend to see imams as "a Muslim equivalent of a rabbi or a priest"; M. Hashas, J.J. de Ruiter, N.V. Vinding, Kh. Hajji, op. cit., p. 24. 


\section{Imams in the West and their classification}

With the influx of Muslim immigrants in the second half of the twentieth century, imams emerged in Western Europe or the United States, especially as the presence of Muslim communities became more stable in the 1970s as a result of family reunification who began to lead religious lives. However, with the stabilization of Muslim communities in the West, the organization of prayer rooms or the construction of mosques, imams start to function differently than in their countries of origin, i.e., besides conducting prayers, they perform many other duties that stem from a lack of support in local religious and legal structures. As Jane I. Smith notes,

[...] traditionally, the imam has been only one of a range of religious leaders with specific roles to play for the Muslim community. It is only in the West, and here in America, that imams may be expected to assume all or many of the roles played by Christian (and often Jewish) leaders. While imam technically means one who leads the prayer, in the largest mosques in the United States, imams perform all the functions of full religious leadership - including preaching, pastoral counselling, business administration, and many of the other service required to make an institution function effectively. ${ }^{13}$

No wonder then that researchers have dealt with this specific situation of imams in Europe or the United States. Though, as Mohammed Hashas, Jan Jaap de Ruiter, Niels Valdemar Vinding, and Khalid Hajji notice, in the beginning, religious leadership was not a crucial topic of the research on Islam in Europe, and researchers focused rather on an "integration of second-generation immigrants, citizenship, loyalty, secularization, modernity, and representative bodies of Islam." 14

Slowly, however, there started to appear studies devoted to not only the role of imams in the integration of Muslim immigrants or in preventing the radicalization of the Muslim youth but also to more general issues, i.e., to their distinctiveness or education, to the way of building their religious authority or functioning in particular countries. ${ }^{15}$ First, researchers developed some typologies alongside other research into imams working in the West, based on differentiating between their religious authority, education and training as imams, and the distinctiveness of their institutional

13 Jane I. Smith, op. cit., p. 67.

${ }^{14}$ M. Hashas, J.J. de Ruiter, N.V. Vinding, Kh. Hajji, op. cit., p. 22.

${ }^{15}$ For example: The Study of Religion and the Training of Muslim Clergy in Europe: Academic and Religious Freedom in the 21 $1^{\text {st }}$ Century, W. Drees, P.S. van Koningsveld (eds.), Leiden 2008; D. Hussain, H. Tuck, Education and Training of Islamic Faith Leaders in Europe: A Comparative Evaluation of Approaches in France and Germany, London 2010; R. Ceylan, Die Prediger des Islam. Imame - wer sind sie und was sie wirklich wollen, Freiburg 2010; J. Ferreiro Galguera, Islam and State in the EU: Church-State Relationships, Reality of Islam, Imams Training Centers, Frankfurt am Main 2011; Imame und Frauen in Moscheen im Integrationsprozess. Gemeindepädagogische Perspektiven, M. Borchard, R. Ceylan (eds.), Osnabrück 2011; The Training of Imams and Teachers for Islamic Education in Europe, E. Aslan, Z. Windisch (eds.), Frankfurt am Main 2012; Islamische Theologie in Österreich. Institutionalisierung der Ausbildung von Imamen, SeelsorgerInnen, und TheologInnen, E. Aslan (ed.), Frankfurt am Main 2013; S. Gilliat-Ray, M.M. Ali, S. Pattison, Understanding Muslim Chaplaincy, Abingdon-onThames 2013; E. Aslan, E. Erşan Akkılıç, J. Kolb, op. cit; Imams in Western Europe. Developments, Transformations, and Institutional Challenges, M. Hashas, J.J. de Ruiter, N.V. Vinding (eds.), op. cit. 
legitimacy, which was necessary to understand the way they function. However, the majority of studies focus on one country, narrowing the proposed division to one type of institutional legitimacy (resulting from a country-specific type of state-religion relation $\mathrm{s}^{16}$ ), often limiting the ethnic or religious spectrum (e.g., the majority of Muslims in Germany and Austria are the Turks, and in Great Britain - Pakistanis, Bangladeshis, and Indus ${ }^{17}$ ), and the resulting divisions are not general enough to apply to all imams in Europe or the United States.

The first fully developed typology of imams in the West is the study by Niels Valdemar Vinding, Towards a Typology of Imams in the West,${ }^{18}$ as the author himself points out, "based on qualitative interviews with about 50 imams in Western Europe and North America ('the West')."19 When preparing his classification, Vinding built on existing research on imams and their divisions; next, he analysed the institutional and epistemic authority that characterizes imams in the West and then interviewed 50 out of 300 identified imams. For his interviewees, he chose imams "who had previously reflected publicly and systematically on what it means to be an imam and the challenges that come with a global, multicultural, and post-migration 'Western' world." ${ }^{20}$ Table 1 (p. 84) is a result of his studies.

It is evident that Vinding's classification covers many countries, ethnic backgrounds of Muslim communities, takes into account imams operating in different legal state-religion relations, with different legal statuses of Islam, because, e.g., in Belgium, Finland or Austria, Islam is officially recognized as religion, while in Germany, Great Britain or France, for various reasons, Islam does not have this status. ${ }^{21}$ However, besides Finland where the Muslim Tatars have lived since the nineteenth century, the classification does not include imams from areas inhabited by the indigenous Muslims. Would they fit into this classification?

${ }^{16}$ For more details see for example: Muslim Minority-State Relations: Violence, Integration, and Policy, R. Mason (ed.), Basingstoke 2016, J.S. Fetzer, J.Ch. Soper, Muslims and the State in Britain, France, and Germany, Cambridge 2005; Islamic Organisations in Europe and the USA. A Multidisciplinary Perspective, M. Kortmann, K. Rosenow-Williams (eds.), Basingstoke-New York 2013.

${ }^{17}$ For Germany: R. Ceylan, op. cit.; for Austria: E. Aslan, E. Erşan Akkılıç, J. Kolb, op. cit.; for the United Kingdom: S. Gilliat-Ray, M.M. Ali, S. Pattison, op. cit.

${ }^{18}$ N.V. Vinding, Towards a Typology of Imams in the West, [in:] Imams in Western Europe. Developments, Transformations, and Institutional Challenges, M. Hashas, J.J. de Ruiter, N.V. Vinding (eds.), op. cit., pp. 231-254.

19 Ibidem, p. 231.

${ }^{20}$ Ibidem, p. 244.

${ }^{21}$ For more details see: A.S. Nalborczyk, Muslim Minorities - A Challenge for the European System of Relations between the State and Religion?, [in:] European Multiculturalism as a Challenge - Policies, Successes and Failures, Wojciech Janicki (ed.), Lublin 2007, pp. 137-153; Muslim Minority-State Relations..., op. cit.; J. Fetzer, Ch. Soper, op. cit.; Islamic Organisations in Europe and the USA..., op. cit. 
Table 1. Typology of 'Imams of the West'

\begin{tabular}{|c|c|c|c|}
\hline \multirow{2}{*}{$\begin{array}{l}\text { Epistemic Autho- } \\
\text { rity/ Institutional } \\
\text { Authority }\end{array}$} & \multicolumn{2}{|c|}{ Formal training or education } & \multirow[b]{2}{*}{$\begin{array}{l}\text { Informal or no trai- } \\
\text { ning or education }\end{array}$} \\
\hline & $\begin{array}{c}\text { Western, secular } \\
\text { education }\end{array}$ & Traditional training & \\
\hline $\begin{array}{l}\text { Institutional imams } \\
\text { and chaplains em- } \\
\text { ployed in hospitals, } \\
\text { prisons, universities, } \\
\text { armed forces }\end{array}$ & $\begin{array}{l}\text { Institutionally alig- } \\
\text { ned imams } \\
\text { Monawar Hussain } \\
\text { United Kingdom }\end{array}$ & $\begin{array}{l}\text { Legitimized institu- } \\
\text { tional imams } \\
\text { Asim Hafiz } \\
\text { United Kingdom }\end{array}$ & $\begin{array}{l}\text { Self-taught chaplain } \\
\text { imams } \\
\text { Tanvir Ahmed } \\
\text { United Kingdom }\end{array}$ \\
\hline $\begin{array}{l}\text { Ambassador or } \\
\text { Network imams } \\
\text { employed by bilateral } \\
\text { or larger international } \\
\text { networks }\end{array}$ & $\begin{array}{l}\text { Western-trained } \\
\text { ambassador imams } \\
\text { Ramil Balyev, Tatars } \\
\text { Finland }\end{array}$ & $\begin{array}{l}\text { Traditionally tra- } \\
\text { ined ambassador } \\
\text { imams } \\
\text { Senad Kusur } \\
\text { Austria }\end{array}$ & $\begin{array}{l}\text { Self-taught network } \\
\text { imam } \\
\text { Ani Zonneveld } \\
\text { United States }\end{array}$ \\
\hline $\begin{array}{l}\text { Imams with local } \\
\text { mosques, associa- } \\
\text { tions or organiza- } \\
\text { tions, either separate } \\
\text { or organized into } \\
\text { smaller networks }\end{array}$ & $\begin{array}{l}\text { Western-trained } \\
\text { local mosques imam } \\
\text { Brahim Laytous } \\
\text { Belgium }\end{array}$ & $\begin{array}{l}\text { Traditionally tra- } \\
\text { ined local mosque } \\
\text { imam } \\
\text { Muhammad Muslim } \\
\text { Eneborg } \\
\text { Sweden }\end{array}$ & $\begin{array}{l}\text { Self-taught mosque } \\
\text { imam } \\
\text { Tareq Oubrou } \\
\text { France }\end{array}$ \\
\hline $\begin{array}{l}\text { Independent imams, } \\
\text { either loosely or not } \\
\text { at all associated with } \\
\text { any kind of institutio- } \\
\text { nal authority }\end{array}$ & $\begin{array}{l}\text { Western-trained } \\
\text { independent imam } \\
\text { Halima Krausen } \\
\text { Gemany }\end{array}$ & $\begin{array}{l}\text { Traditionally tra- } \\
\text { ined independent } \\
\text { imam } \\
\text { Salahuddin Barakat } \\
\text { Sweden }\end{array}$ & $\begin{array}{l}\text { Self-taught indepen- } \\
\text { dent imam } \\
\text { Abdul Wahid Petersen } \\
\text { Denmark }\end{array}$ \\
\hline
\end{tabular}

Source: N.V. Vinding, Towards a Typology of Imams in the West, [in:] Imams in Western Europe. Developments, Transformations, and Institutional Challenges, M. Hashas, J.J. de Ruiter, N.V. Vinding (eds.), Amsterdam 2018, p. 245 .

As the author points out, this classification is merely a "work in progress and an invitation for further discussion on how, and according to which parameters, to systematize the study of diverse types of imams in the West." ${ }^{22}$ Thus, an interesting question arises: whether this classification also applies to imams in those parts of Europe where Muslims have been present for so long that they are indigenous peoples, but the traditional Muslim world sees these countries as the West. With the Muslim minority present within its borders since the seventeenth century, Poland exemplifies such a region, where there have been changes in the way Muslim religious community ${ }^{23}$ operates and in its legal status; recently, since the 1980s, its ethnic composition has also changed, which must have impacted the status and functioning of imams. Will this typology also work in a diachronic perspective?

${ }^{22}$ N.V. Vinding, op. cit., p. 250.

${ }^{23}$ For more details see: A.S. Nalborczyk, P. Borecki, Relations between Islam and the State in Poland: The Legal Position of Polish Muslims, "Islam and Christian-Muslim Relations" 2011, no. 22 (3), pp. 343-359. 


\section{Polish-Lithuanian Tatar imams in the past}

The Polish-Lithuanian Tatars come from the Golden Horde, a state that officially adopted Sunni Islam in the thirteenth century. In the fourteenth century, because of extensive and diverse relations between the Golden Horde and the Grand Duchy of Lithuania, they began to appear within Lithuania, but their settlement was particular. Some of them were prisoners of war; some political refugees who, following unsuccessful struggles for power, had to seek shelter outside the Golden Horde, but there were also many brought by the Grand Duke (called hospodar) to help the Lithuanian army defend the borders against enemies, especially the Teutonic Order. Some refugees were also soldiers who found their place in units fighting on the Lithuanian side. Because of their military service, the Tatar population enjoyed many privileges, including fiefdoms (known as ziemia hospodarska) granted by the duke, religious freedom, and a legal and social status similar to that of the Lithuanian nobility. The Tatars were directly subject to the duke's authority; they served in their cavalry units (known as choragiew); in peacetime, they operated following the territorial military organization, and the commander (choraży) was in charge of administration. The Tatar settlers were also part of other social strata, such as messengers, gardeners, or saddlers.

Tatars as Sunni Muslims of the Hanafi School, who enjoyed the freedom of religion, ${ }^{24}$ practiced Islam and erected mosques called by them dzamija (Arab. jam 'iya) or mieczeć (Arab. masjid).$^{25}$ Earliest mosques were built in the very beginning of the settlement, ${ }^{26}$ and in the seventeenth century, there were already around 30 mosques on the territory of the Polish-Lithuanian state. ${ }^{27}$ Local religious communities usually organized around mosques were called dżamiat/dżemiat or more rarely ummiet (Arab. umma), and their imams, religious leaders, were called mottna, matna, motta or mutta (mulla; Arab. mawla).$^{28}$ The upkeep of a mosque and an imam was

${ }^{24}$ P. Borawski, O sytuacji wyznaniowej ludności tatarskiej w Wielkim Księstwie Litewskim w Polsce (XVI-XVIII w.), "Euhemer - Przegląd Religioznawczy" 1980, no. 118 (4), pp. 43f; J. Tyszkiewicz, Tatarzy w Polsce i Europie. Fragmenty dziejów, Pultusk 2008, pp. 151f. There were no serious attempts to convert them to Christianity - P. Borawski, A. Dubiński, Tatarzy polscy. Dzieje, obrzędy, tradycje, Warszawa 1986, p. 74; A.B. Zakrzewski, O asymilacji Tatarów w Rzeczypospolitej w XVI-XVIII w., [in:] Tryumfy i porażki. Studia z dziejów kultury polskiej XVI-XVIII w., M. Bogucka (ed.), Warszawa 1989, pp. 87-89.

${ }^{25}$ S. Kryczyński, Tatarzy litewscy. Próba monografii historyczno-etnograficznej, Gdańsk 2000 [1938], p. 166.

${ }^{26}$ There is a record from 1558 on mosques in Lithuania; ibidem, p. 159.

${ }^{27}$ For more details see: P. Borawski, op. cit., pp. 44f.; A.B. Zakrzewski, Osadnictwo tatarskie w Wielkim Księstwie Litewskim - aspekty wyznaniowe, "Acta Baltico-Slavica" 1989, no. 20, p. 140. For more details concerning mosques in the Polish-Lithuanian state, see: A.S. Nalborczyk, Mosques in Poland. Past and present, [in:] Muslims in Eastern Europe. Widening the European discourse on Islam, K. Górak-Sosnowska (ed.), Warsaw 2011, pp. 183-184.

${ }^{28}$ Risāle-i Tātār-i Leh [1558] transl. A. Muchliński, [in:] Zdanie sprawy o Tatarach litewskich przez jednego z tych Tatarów złożone sultanowi Sulejmanowi $w$ r. 1558, z j. tureckiego przełożył, objaśnił i materiałami historycznymi uzupełnił A. Muchliński, "Teka Wileńska" 1858, no. 4, p. 259 (18). On the credibility of Risāle-i Tātār-i Leh as a historical source see: A. Konopacki, Życie religijne Tatarów na 
provided for by estates, mostly farmlands, made over as endowments (waqfs), as lawfully granted to imams by the electoral documents, which served as an agreement with the diemiat, but waqfs often did not generate enough income. ${ }^{29}$ Imams also received remuneration for their service directly from the believers, for example, for praying for the dead; they also collected the so-called fitra for visiting houses in the second half of Ramadan - paid in money or nature. ${ }^{30}$

The dizemiats held meetings led by the land military commander (chorazy) of a given district (poviat), and their participants discussed not only matters related to the community ${ }^{31}$ but also elected their imams. ${ }^{32}$ The election criteria included being "able to learn, from a good family, and with a decent manner around the parish," as the imam of the Łowczyce mosque, Achmeć Assanowicz, wrote in 1820 in a memorial to the Russian authorities. ${ }^{33}$ Therefore, there were no formal requirements regarding an imam's education ${ }^{34}$; he had to be well-born, know the rules of religion, be able to lead a prayer, recite the Qur'an, and inspire the respect of the faithful. ${ }^{35}$ As a result, the imams sometimes did not understand the Qur'an in Arabic, although they knew it by heart, and they had tafsirs (comments), which were translations in Polish, Belarusian or Russian. ${ }^{36}$ Interestingly, an imam often was the son of the previous imam, ${ }^{37}$ for instance, the documents prove that for 65 years, since 1791, in Studzianka the imams came from the same Okmiński family. ${ }^{38}$ It is worth noting that at the beginning of the Tatar settlement, but also later, in the sixteenth-seventeenth century, imams were brought from neighbouring Muslim territories, e.g., from Crimea, ${ }^{39}$ while sometimes young Tatars were sent to Crimea to study. ${ }^{40}$

ziemiach Wielkiego Księstwa Litewskiego w XVI-XIX w., Warszawa 2010, p. 86. Imams serving in larger communities were called chatyp (Arab. khatib); S. Kryczyński, op. cit., pp. 170-173. People of other denominations referred to imams using terms derived from Christianity. There are documents with phrases such as a 'Tatar pop' [pop meaning in Polish 'an Orthodox clergyman'] or 'their priest motna' (mulla); there is an entry "Eljasz Okmiński, a Mohammedan priest" in the record book. A. Konopacki, op. cit., pp. $85-86,192$.

${ }^{29}$ Ibidem, pp. 86-87.

${ }^{30}$ S. Kryczyński, op. cit., p. 176. Perhaps they were inspired by priests' pastoral visits.

${ }^{31}$ Ibidem, p. 169.

${ }^{32}$ A. Zakrzewski, Osadnictwo tatarskie..., op. cit., p. 140. There are documents regarding the election, for more details see: A. Konopacki, op. cit., p. 86.

${ }^{33}$ L. Kryczyński, Historia meczetów w Łowczycach i Nowogródku, "Przegląd Islamski" 1934, no. 3-4, pp. 15-17.

${ }^{34}$ A. Konopacki, op. cit., pp. 85f.

35 A. Zakrzewski, Osadnictwo tatarskie..., op. cit., p. 141.

${ }^{36}$ S. Kryczyński, op. cit., p. 154.

${ }^{37}$ A. Konopacki, op. cit., p. 176.

${ }^{38} \mathrm{Ibidem}, \mathrm{p} .188$. It was probably because imams often passed knowledge only to their to ensure that their status, as well as the material means obtained from waqfs, remained in the family.

${ }^{39}$ Risāle-i Tātār-i Leh, op. cit., p. 258 (18); P. Borawski, Asymilacja kulturowa Tatarów w Wielkim Księstwie Litewskim, "Odrodzenie i Reformacja w Polsce" 1992, no. 26, p. 174.

40 J. Tyszkiewicz, Tatarzy na Litwie $i$ w Polsce, Warszawa 1989, p. 292. The cooling down of political relations with Crimea resulted in a school in Vilnius, where young Tatars learned Arabic since 1570 so that there was no need to bring imams from abroad. It existed throughout the seventeenth century, then the level of education started to decline; A. Zakrzewski, $O$ asymilacji..., op. cit., pp. 90-96. 
The official status of Tatar imams was not regulated by any state law; they were not even mentioned in any act. ${ }^{41}$ The role of an imam was not limited solely to religious duties. It is worth noting that they also acted as a community representative before the courts and offices, administered oaths, ${ }^{42}$ and kept a register of births and deaths. ${ }^{43}$ Thus, like a priest, an imam also took on the role of an official: recording births, deaths, as well as officiating weddings, granting divorces and registering them. ${ }^{44}$ The royal authorities used imams as mediators when they wanted to issue orders to the Tatar community or collect taxes; an imam also served as a chancellor and a notary, certifying documents or issuing certificates of noble origin. ${ }^{45} \mathrm{He}$ was very often entrusted with important documents and valuable property for safekeeping. Imams would also serve as witnesses during significant events. ${ }^{46}$

When the Polish-Lithuanian Commonwealth lost its independence at the end of the eighteenth century, the lands inhabited by the Tatars came under the Russian rule. However, not much changed for the diemiats or imams. Because of an organizational reform of the religious life of Muslims in Russia, Polish-Lithuanian Tatars became subordinates of the Muftiate in Simferopol, but they retained their right to elect their imams ${ }^{47}$ (formally, the nomination of an imam had to be approved by the governorate authorities and then by the $\mathrm{Mufti}^{48}$ ).

\section{Polish-Lithuanian Tatar imams in the interwar period}

In 1918, after World War I, Poland regained its independence. This war was a tragedy for the Tatar-Muslim community: mosques were burned, cemeteries destroyed, and many Tatar families found themselves in exile, in the interior of Russia. The leadership of the Muftiate in Simferopol was dissolved after the Bolsheviks seized Crimea.

In 1925, the first all-Polish religious organization of Polish Muslims was established - Muzułmański Związek Religijny w Rzeczypospolitej Polskiej (Muslim Religious Union in the Republic of Poland - henceforth MZR) and the first Mufti, an orientalist Dr. Jakub Szynkiewicz, was elected. The activities of MZR were based on local Muslim communities, of which there were 19 in the interwar period; in 1925,

41 P. Borawski, O sytuacji wyznaniowej..., op. cit., p. 52.

${ }^{42}$ Ibidem, pp. 51-52; J. Sobczak, Położenie prawne ludności tatarskiej w Wielkim Księstwie Litewskim, Warszawa-Poznań 1984, p. 77.

43 The oldest register found comes from a mosque in Nowogródek and dates back to 1784; A. Konopacki, op. cit., p. 292. In the eighteenth century, registers were kept in Polish, but in the nineteenth century, after Poland lost independence, Russian authorities ordered to keep them in Russian - S. Kryczyński, op. cit., p. 173.

44 Ibidem.

45 A. Konopacki, op. cit., p. 87. Some of the imams' duties were modeled on their Christian neighbors, like calling an imam to a seriously ill person or saying a prayer for the dead in a mosque; P. Borawski, Asymilacja kulturowa..., op. cit., p. 184.

46 S. Kryczyński, op. cit., p. 174.

${ }^{47}$ A. Konopacki, op. cit., p. 168.

48 J. Tyszkiewicz, Z historii Tatarów polskich 1794-1944, Pułtusk 2002, p. 82. 
18 imams and 12 muezzins served in these communities, in 1935: 19 imams and 22 muezzins. Initially, each of the communities was headed by the Board. However, in 1936, the Polish parliament introduced the Act on the Relations Between the State and the Muslim Religious Union. According to the Act, an imam was at the head of every community. He was elected similarly to a muezzin, ${ }^{49}$ his deputy and assistant, by the general assembly of members of a given religious community. ${ }^{50}$ Muezzins helped imams and prayed in hamlets distant from the "parochial" mosque. The upkeep of imams and muezzins was still provided for by waqf properties. Also, they received salaries from the state funds transferred by the Muftiate. They also received offerings from individual believers for a specific religious service or prayer. Imams were responsible not only for religious services, but (as they had in the past under the authority of the Muftiate in Simferopol) also served as registrars and civic officials: conducting weddings and granting divorces, keeping records and issuing marriage or birth certificates, and the like.

During their time, the MZR authorities noticed a low level of schooling among imams: they mostly had elementary education, and another imam was very often the only source of their religious knowledge. Therefore, there were attempts at further education, e.g., an internal course for younger imams and hodżas (teachers of religion; Per.-Tur. khoja). ${ }^{51}$ Another MZR initiative was sending young Tatars to study in Muslim centres abroad. ${ }^{52}$ Sending Tatar students to the pre-eminent Sunni Muslim university, i.e., Egyptian Al-Azhar University, proved to be the most significant achievement. However, only one Al-Azhar graduate, Ali Ismail Woronowicz, became an imam in the Warsaw community after his return. He was also a military chaplain: a field imam for the Tatar light cavalry squadron in the Polish army. Later, young people were sent (at the Muftiate's expense) to study in Bosnia, ${ }^{53}$ mostly to the madrasa by the Gazi Husrev-bey mosque, a Muslim secondary school, with Arabic, Persian and Turkish, secular and theological subjects. Until World War II, three students left to study there, for instance Jusuf Konopacki returned to Poland but never became an imam. $^{54}$

\section{Contemporary imams in Poland}

After World War II, as a result of moving the Polish borders to the West, only three traditional Muslim communes remained within the Polish state (in Warsaw, Bohoniki, and Kruszyniany). As a result of the resettlements that followed, the Tatars were

49 Often, a muezzin became imam after the death of the previous imam.

50 S. Kryczyński, op. cit., p. 172.

51 U. Wróblewska, Oświata Tatarów w Drugiej Rzeczypospolitej, Warszawa 2012, pp. 82-83.

52 S. Kryczyński, op. cit., pp. 176-177.

53 Russia was not taken into account, despite the nineteenth-century tradition of communication with its Muslim ethnic groups, as it was under the hostile Soviet rule.

${ }^{54}$ U. Wróblewska, op. cit., p. 80. Probably because of his mainstream version of the Islamic practice from Bosnia, which differed from the practice passed on by the Tatar imams. 
scattered, finding themselves in the so-called Western territories without the religious infrastructure which remained in the East. Although the MZR was reactivated in 1947, the spiritual life of Muslims was not easy. Imams educated before the war performed the service; however, there were not enough of them, and with time, their numbers declined due to natural causes. On the other hand, for financial and political reasons, it was difficult for the youth to study Islam abroad. The larger Tatar communities, like in Podlasie or Gdańsk, managed to maintain a long-term service of imams. However, there were also local communities consisting of only presidents of the communities and the believers, and with temporary imams. In these cases, none of the Tatar residents had adequate education, and random individuals performed the service, often students of Arab origin, as was the case in Bydgoszcz. For a long time, the local community in Warsaw did not have a permanent imam, although Muslim members of the diplomatic corps attended the prayers and embassies of Muslim countries, particularly Egypt, at their own expense, would bring an imam to Warsaw for the Muslim religious holidays after which the imam would return to his homeland. Frequently, an employee of one of the Muslim embassies (e.g., for a long time it was an employee of the Bangladesh embassy) conducted the prayer.

Following the political changes of 1989, Poland became a democratic state with open borders; a country in which it was easier for the religious communities to operate. New legal regulations regarding state-religion relations were adopted - the foundation for the current legal and organizational situation of Islam in Poland. They introduced an easier registration of denominational organizations and, consequently, an organizational pluralism for the Muslim religious life - until that moment, only the Muslim Religious Union in the Republic of Poland was officially active..$^{55}$

There are currently five Muslim denominational organizations registered in Poland; imams operate only within them, and there are no independent imams. Within the frame of the MZR, there are one mufti and nine imams, each of them assigned to a mosque or a prayer room. Mufti Tomasz Miśkiewicz and two imams (Janusz Aleksandrowicz in the Kruszyniany mosque and Aleksander Bazarewicz in the Bohoniki mosque) are of Tatar origin, but the mufti is the only one with formal theological education, ${ }^{56}$ while the other two acquired knowledge in various centres abroad, in Europe and beyond. Two imams, Ramil Khayrow in the prayer room in Suchowola and Mirzogolib Radhabaliev in the prayer room in Białystok (MZR's headquarters, where he serves together with the mufti), come from Russia and live in Poland as a result of agreements between Mufti Miśkiewicz and the Mufti of Tatarstan. These are two imams with the traditional Muslim theological education, and since Russian is, like Polish, a Slavic language, they have quickly learned the language of their community. The remaining three imams are Ismail Çaylak in the Gdańsk mosque, Vahid Ercan in the prayer room of the Tatar Cemetery in Warsaw, and Abdülkarim Gök in the prayer room of the Turkish-speaking Fatih local community. These imams

${ }^{55}$ For more details see: A.S. Nalborczyk, M. Ryszewska. Islamic Organizations in Poland: From Monopoly to Pluralism, [in:] Islamic Organizations in Europe and the USA. A Multidisciplinary Perspective, M. Kortmann, K. Rosenow-Williams (eds.), Basingstoke-New York 2013, pp. 24-27.

${ }^{56}$ For more details see: A.S. Nalborczyk, Poland ..., op. cit., pp. 305-308. 
came from Turkey under the mufti's agreement with the Turkish authorities; thus, they are traditionally theologically educated. However, because the Muslims under their care are not Turkish-speaking (besides the Fatih community), language problems happen, especially at the cemetery in Warsaw. While the imam of the Warsaw community, officially named on the MZR's website, Aboubacar Moussa Ali, comes from Egypt, the majority of worshippers are of foreign origin, with a significant percentage of people of Arabic origin, so language is not a problem. Their previous official imam, Nezar Charif, is a Syrian with the traditional Syrian religious education, who has served in this community for many years and speaks Polish very well; he does not appear on the official MZR's website as the imam of this community due to a conflict with the mufti.

The entire Shi'a organization is relatively small: with three imams, Polish converts to Shi'a Islam, and around 50 people attending prayers. Two younger imams, Rafał Berger and Arkadiusz Miernik, first gained knowledge from imam Mahmud Taha Żuk (a Catholic theology graduate from the Warsaw Theological Academy, in 1994, he took a monthly theological course in Tunisia), who then examined them as the chief imam. Currently, Rafał Berger is the chief imam, elected by the members of the organization. Arkadiusz Miernik continued his education in the Shi'a theological seminary abroad and now lives in London.

The second Sunni organization, Liga Muzułmańska w Rzeczypospolitej Polskiej (the Muslim League in the Republic of Poland - henceforth LM) registered in 2004, was founded by former students of Arab origin, their families, and converts. It has branches in several major Polish cities and its imams, usually of Arab descent, mainly come from local communities. It happens, as in the only purpose-built mosque at the LM's disposal, that the imam comes from an Arab country (in this case, he came from Yemen, has a traditional education, and has learned Polish very quickly). ${ }^{57}$

The Act of 1936 on Relations Between the State and the Muslim Religious Union provides a possibility of establishing a Muslim ministry in the Polish Army, hospitals and prisons "as needed." Currently, there are no Muslim chaplains permanently employed in public institutions. The reason is purely sociological, i.e., a relatively small number of Muslim citizens - 0.09-0.1 percent of the whole population.

\section{Conclusions - does the typology of imams in the West work for the Tatars?}

Researchers of Islam in the West have noticed that imams working since the 1950s in Western Europe or the United States assume far more responsibilities than their counterparts in traditional Muslim societies. Imams perform many more roles, including leading prayers, as well as preaching, pastoral counselling, mosque administration, health counselling, organizing cultural and other free-time activities for the

${ }^{57}$ However, it turns out that due to the linguistic diversity of the Warsaw congregation (diplomats, expats, guest workers), English is also necessary. 
community members, and many others. These services are similar to those performed by the Christian clergy. Consequently, further research had to identify and specify the types of imams who perform their service in the West - their most comprehensive typology is the one developed by Niels Valdemar Vinding. ${ }^{58}$

It turns out that imams working in the communities of the Polish-Lithuanian Tatars, considered as existing in the West for the traditional Muslim communities, have long been playing a role similar to that of priests. As the available historical sources show, not only did they conduct prayers, but also administrated the mosque and its waqfs, protected the goods entrusted to them, took oaths, and - in the nineteenth and early twentieth century - kept the birth, burial, marriage registers on a par with those maintained by the clergy of other denominations. Every imam was assigned to a given mosque and a mosque to a given congregation that lived nearby and elected the imam. It is no coincidence that in the historical sources as well as in the Muslim documents, communities of mosques are "parishes," and imams are called "imam of such and such parish."

As the analysis presented above demonstrates, Vinding's typology also applies to imams working in the indigenous Muslim communities, although there is a preponderance of some types, while others are non-existent. Tatar imams "with local mosques" (or prayer rooms), according to Vinding's typology, imams of particular Muslim communities, prevailed in the Polish-Lithuanian state. In the past, these communities (dizemiats) were separate; only in the nineteenth century, they came under the joint authority of the Muftiate in Simferopol, while remaining independent in the election of imams. Throughout this period, the education of imams was traditional, one imam learning from another, like a son from a father, making this training informal, which could mean "self-taught" in Vinding's classification. Later, one all-Polish organization was established, the Muslim Religious Union in the Republic of Poland, but imams were still assigned to local communities and, despite attempts, only a small percentage of them received regular, formal theological education ("traditionally trained" in Vinding's typology). Throughout the history of imams in the PolishLithuanian and Polish state, local communities elected their imams.

Imams currently working in Poland are still associated with specific centres or organizations, and their education varies: from informal, provided by other followers or as part of self-education, to the traditional formal education of imams brought from Muslim countries ("ambassador or network imams" in Vinding's typology). Interestingly, the Tatars were already bringing imams-ambassadors from Crimea in the sixteenth century.

As the basis of his typology, Vinding distinguishes two types of authority: institutional and epistemic. Institutional authority is assigned to "institutional power of the employer, organization, or network that engages the imam and therefore delegates unto and authorizes the imam in his conduct and business as an imam". ${ }^{59}$ Epistemic authority is, as Vinding notes, based on "the kind of training (formal or informal), accumulation of knowledge, or recognition of merit that demonstrate that the qualities

${ }^{58}$ N.V. Vinding, op. cit., p. 244-249.

${ }^{59}$ Ibidem, p. 242. 
of an individual are sufficient for him to conduct the business of an imam, regardless of what kind of employment or function as imam or chaplain he might have". ${ }^{60}$ Islamic knowledge is one of the most important sources of Islamic authority for the imam.

The functioning of imams in Poland has always been based more on the institutional authority than the epistemic authority (education and training have been and remains not that important), it was and is authorized by the community itself by election. The education of imams was usually poor; inspiring respect from the community or coming from a good family was much more vital. It was not until the twentieth century that education started to play a more significant role, but it is clear that completing formal religious education is still unnecessary.

It is therefore evident that the typology developed for imams in Western Europe and the United States also might be applied to imams working in indigenous European Muslim communities. However, in these communities, there is a preponderance of some types identified by Vinding ("imams with mosques"), while others do not occur at all (e.g., "independent imams") or are very rare ("self-taught chaplain imams").

\section{References}

Aslan E., Erşan Akkılıç E., Kolb J., Imame und Integration, Berlin-New York 2015.

Borawski P., Asymilacja kulturowa Tatarów w Wielkim Księstwie Litewskim, "Odrodzenie i Reformacja w Polsce" 1992, no. 26, pp. 163-191.

Borawski P., O sytuacji wyznaniowej ludności tatarskiej w Wielkim Księstwie Litewskim w Polsce (XVI-XVIII w.), "Euhemer - Przegląd Religioznawczy" 1980, no. 118 (4), pp. 43-53.

Borawski P., Dubiński A., Tatarzy polscy. Dzieje, obrzędy, tradycje, Warszawa 1986.

Ceylan R., Die Prediger des Islam. Imame - wer sind sie und was sie wirklich wollen, Freiburg 2010.

Ferreiro Galguera J., Islam and State in the EU: Church-State Relationships, Reality of Islam, Imams Training Centers, Frankfurt am Main 2011.

Fetzer J.S., Soper J.Ch., Muslims and the State in Britain, France, and Germany, Cambridge 2005. Fröhlich A.-S., Priesterliche Aufgaben im sunnitischen Islam, Hamburg 1997.

Gilliat-Ray S., Ali M.M., Pattison S., Understanding Muslim Chaplaincy, Abingdon-on-Thames 2013.

Hashas M., de Ruiter J.J., Vinding N.V., Hajji Kh., Imams in Western Europe. Developments, Transformations, and Institutional Challenges, [in:] Imams in Western Europe. Developments, Transformations, and Institutional Challenges, M. Hashas, J.J. de Ruiter, N.V. Vinding (eds.), Amsterdam 2018, pp. 19-37.

Hussain D., Tuck H., Education and Training of Islamic Faith Leaders in Europe: A Comparative Evaluation of Approaches in France and Germany, London 2010.

Imame und Frauen in Moscheen im Integrationsprozess. Gemeindepädagogische Perspektiven, M. Borchard, R. Ceylan (eds.), Osnabrück 2011.

Imams in Western Europe. Developments, Transformations, and Institutional Challenges, M. Hashas, J.J. de Ruiter, N.V. Vinding (eds.), Amsterdam 2018.

Islamic Organisations in Europe and the USA. A Multidisciplinary Perspective, M. Kortmann, K. Rosenow-Williams (eds.), Basingstoke-New York 2013.

${ }^{60}$ Ibidem, pp. 242-243. 
Islamische Theologie in Österreich. Institutionalisierung der Ausbildung von Imamen, SeelsorgerInnen, und TheologInnen, E. Aslan (ed.), Frankfurt am Main 2013.

Konopacki A., Życie religijne Tatarów na ziemiach Wielkiego Księstwa Litewskiego w XVI-XIX w., Warszawa 2010.

Kryczyński L., Historia meczetów w Łowczycach i Nowogródku, "Przegląd Islamski" 1934, no. 3-4, pp. $15-17$.

Kryczyński S., Tatarzy litewscy. Próba monografii historyczno-etnograficznej, Gdańsk 2000 [1938].

Madelung W., Imāma, [in:] The Encyclopaedia of Islam. Second Edition, vol. 3, B. Lewis, V.L. Ménage, Ch. Pellat, J. Schacht (eds.), Leiden-London 1986, pp. 1163-1169.

Muslim Minority-State Relations: Violence, Integration, and Policy, R. Mason (ed.), Basingstoke 2016.

Nalborczyk A.S., Mosques in Poland. Past and Present, [in:] Muslims in Eastern Europe. Widening the European Discourse on Islam, K. Górak-Sosnowska (ed.), Warsaw 2011, pp. 183-193.

Nalborczyk A.S., Muslim Minorities - A Challenge for the European System of Relations between the State and Religion?, [in:] European Multiculturalism as a Challenge-Policies, Successes and Failures, Wojciech Janicki (ed.), Lublin 2007, pp. 137-153.

Nalborczyk A.S., Poland, [in:] Islamic Leadership in the European Lands of the Former Ottoman and Russian Empires. Legacy, Challenges and Change, E. Račius, A. Zhelyazkova (eds.), Leiden 2018, pp. 293-313.

Nalborczyk A.S., Polish Tatar Women as Official Leaders of Muslim Religious Communities and the Sources of Their Authority, "Comparative Islamic Studies” 2016 (publ. 2019), no. 12 (1-2), pp. 37-54.

Nalborczyk A.S., Borecki P., Relations between Islam and the State in Poland: The Legal Position of Polish Muslims, "Islam and Christian-Muslim Relations" 2011, no. 22 (3), pp. 343-359.

Nalborczyk A.S., Ryszewska M., Islamic Organizations in Poland: From Monopoly to Pluralism, [in:] Islamic Organizations in Europe and the USA. A Multidisciplinary Perspective, M. Kortmann, K. Rosenow-Williams (eds.), Basingstoke-New York 2013, pp. 13-36.

Pedersen J., Masdjid, G. The Personnel of the Mosque, [in:] The Encyclopaedia of Islam. Second Edition, vol. 6, C.E. Bosworth, E. van Donzel, W.P. Heinrichs, Ch. Pellat (eds.), Leiden 1991, pp. 644-677.

Risāle-i Tātār-i Leh [1558], transl. A. Muchliński, [in:] Zdanie sprawy o Tatarach litewskich przez jednego z tych Tatarów złożone sułtanowi Sulejmanowi w r. 1558, z j. tureckiego przełożył, objaśnił i materiałami historycznymi uzupełnił A. Muchliński, “Teka Wileńska” 1858, no. 4, pp. 241-272 (1-137).

Smith, J.I., Islamic Leadership in America, [in:] Religious Leadership: A Reference Handbook, Sh.H. Callahan (ed.), Thousand Oaks, CA, 2013, pp. 65-73.

Sobczak J., Położenie prawne ludności tatarskiej w Wielkim Księstwie Litewskim, WarszawaPoznań 1984.

The Study of Religion and the Training of Muslim Clergy in Europe: Academic and Religious Freedom in the $21^{\text {st }}$ Century, W. Drees, P.S. van Koningsveld (eds.), Leiden 2008.

The Training of Imams and Teachers for Islamic Education in Europe, E. Aslan, Z. Windisch (eds.), Frankfurt am Main 2012.

Thiele C., Imame in türkisch-sunnitischen Gemeinden in Deutschland. Ihre Rolle und Bedeutungdargestellt anhand der Situation in Hamburg, Nordhausen 2010.

Tyszkiewicz J., Tatarzy na Litwie i w Polsce, Warszawa 1989.

Tyszkiewicz J., Tatarzy w Polsce i Europie. Fragmenty dziejów, Pułtusk 2008.

Tyszkiewicz J., Z historii Tatarów polskich 1794-1944, Pułtusk 2002.

Vinding N.V., Towards a Typology of Imams in the West, [in:] Imams in Western Europe. Developments, Transformations, and Institutional Challenges, M. Hashas, J.J. de Ruiter, N.V. Vinding (eds.), Amsterdam 2018, pp. 231-254. 
Wróblewska U., Oświata Tatarów w Drugiej Rzeczypospolitej, Warszawa 2012.

Zakrzewski A.B., O asymilacji Tatarów w Rzeczypospolitej w XVI-XVIII w., [in:] Tryumfy i porażki. Studia z dziejów kultury polskiej XVI-XVIII w., M. Bogucka (ed.), Warszawa 1989, pp. 76-96.

Zakrzewski A.B., Osadnictwo tatarskie $w$ Wielkim Księstwie Litewskim - aspekty wyznaniowe, "Acta Baltico-Slavica" 1989, no. 20, pp. 137-153. 